Dhaka Univ. J. Sci. 64(2): 153-156, 2016 (July)

\title{
Treatment of Wastewater Containing Brilliant Orange H2R and Brilliant Red M5B by Electrocoagulation

\author{
Hasina Akter $^{1^{*} \text {, Hasina Akhter Simol }{ }^{2} \text { and Shaila Salahuddin }}{ }^{3}$ \\ ${ }^{I}$ Department of CSE \& IT, University of Information Technology and Sciences (UITS), Dhaka-1212, Bangladesh \\ ${ }^{2}$ Centre for Advanced Research in Sciences, Dhaka University, Dhaka-1000, Bangladesh \\ ${ }^{3}$ Department of Civil Engineering, University of Information Technology and Sciences (UITS), Dhaka-1212, Bangladesh
}

(Received: 21 January 2016; Accepted: 17 February 2016)

\begin{abstract}
Treatment of dyeing wastewater containing reactive Brilliant Orange H2R and Brilliant Red M5B dyes were investigated by using electrocoagulation process. The experimental results were analysed in terms of percent removal of dye with time. Electrocoagulation of dye containing wastewater was carried out in a two-electrode monopolar electrocoagulation cell using iron as sacrificial anode and $0.01 \mathrm{M} \mathrm{NaCl}$ as internal electrolyte in which the electrolyte concentration was maintained constant during the experiment. In electrocoagulation the effects of concentration of dye and applied current strength on dye removal efficiency were tested and found that both have significant effects on the electrocoagulation of dye from wastewater.
\end{abstract}

\section{Introduction}

Wastewaters from dyeing and finishing industries are significant sources of environmental pollution. The reactive dyes, which represent the largest class of dyes used in textile processing industries are mostly azo compounds. The azo compounds are formed with one or more several azo $(\mathrm{N}=\mathrm{N})$ bridges linking substituted aromatic structures. These dyes are chemically and photolytically stable, they exihibit a high resistance to microbial degradation and are highly persistent in natural environment. The release of these compounds into the environment is undesirable, not only for asthetic reasons, but also because many azo dyes and their breakdown products are toxic and /or mutagenic for life.

Various physical, chemical and biological pre-treatment, main treatment and post-treatment techniques can be employed to remove color from dye-containing wastewaters ${ }^{1-8}$. Physicochemical techniques include membrane filtration, coagulation/flocculation, flotation, precipitation, adsorption, ion exchange, ion pair-extraction, ultrasonic mineralization, electrolysis, advanced oxidation (chlorination, bleaching, ozonization, fenton oxidation and photocatalytic oxidation) and chemical reduction. Biological techniques include bacterial and fungal biosorption and biodegradation in aerobic, anaerobic, anoxic or combined anaerobic/aerobic treatment process. Since many organic dyes are harmful to human beings, the removal of color from process or waste effluents becomes environmentally important. Due to the large degree of organics and stability of modern dyes, conventional physico-chemical and biological treatment methods are not completely effective for their removal. Furthermore, the treatment cost of the textile wastewater has been escalating fairly rapidly in recent years. Hence search for more cost effective treatment methods has always been an attractive area of research. One of the primary objectives of this study was to investigate the degradation of the two textile dyes Brilliant Orange H2R and Brilliant Red M5B by using in-situ electrocoagulation method with iron as 'sacrificial'

\footnotetext{
Author for correspondence. e-mail: bhasinaakterchem@yahoo.com
}

electrodes. Electrocoagulation technique is applied for treatment of inorganic as well as organic pollutants from wastewater. This is an innovative and inexpensive technique used for treatment of wastewater. With the proper technological design, EC can be applied to a broad spectrum of water and wastewater treatment systems. In the EC process, the coagulant is generated in situ by electrolytic oxidation of an appropriate anode material. In this process, charged ionic species- metals or otherwise - are removed from wastewater by allowing it to react (i) with an ion having opposite charge, or (ii) with floc of metallic hydroxide generated within the effluent.

\section{Experimental}

In the present research synthetic wastewaters containing two reactive textiles dyes Brilliant Orange $\mathrm{H} 2 \mathrm{R}$ dye and Brilliant Red M5B were selected for investigations. The removal of dye from dye containing wastewater by electrocoagulation was carried out by using two electrode electrocoagulation cell (Fig. 1) containing Fe as 'sacrificial electrode $(8 \mathrm{~cm} \times 8 \mathrm{~cm} \times 0.15 \mathrm{~cm})$. This set up includes the electrode assembly, a DC power supply unit, a voltage stabilizer, a resistance box to regulate the current and a multimeter to read the current values. The concentrations of dyes in wastewater were determined spectrophotometrically. The iron-hydroxy adsorbent was produced in-situ to determine the $\%$ of dyes removed by electrocoagulation. The $\%$ of dye removed was calculated by using the following equation:

$$
\% \text { of dye removed }=\left(\mathrm{C}_{\mathrm{o}}-\mathrm{C}_{\mathrm{t}}\right) / \mathrm{C}_{\mathrm{o}} \times 100
$$

where, $\mathrm{C}_{\mathrm{o}}$ and $\mathrm{C}_{\mathrm{t}}$ are the initial concentration of the dye and concentration of the dye at time $t$ after coagulation respectively. The experiments were carried out by varying the dye concentrations as well as by varying the current strength. 


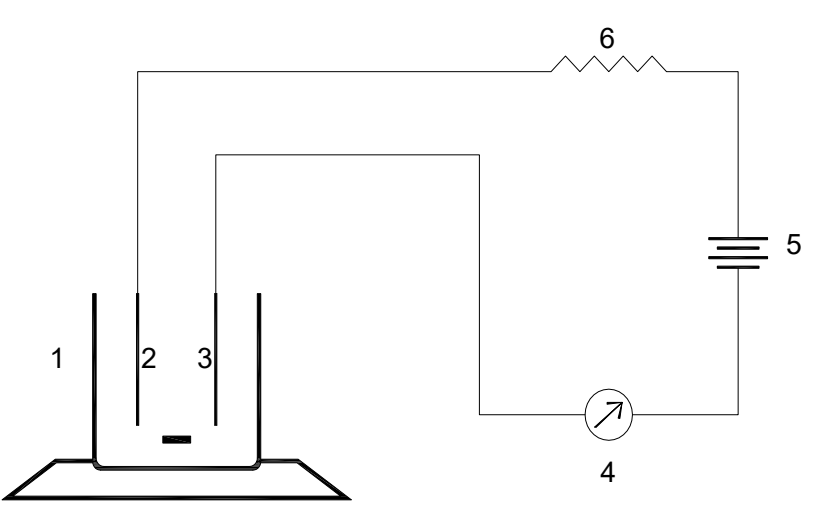

\section{Result and Discussion}

In this series of experiments usually $200 \mathrm{~mL}$ of dye solution of definite concentration was used and 0.25 A current was applied. Sodium chloride $(0.01 \mathrm{M})$ was used as internal electrolyte in all experiments. For Brilliant Orange H2R, the dye concentrations used were 10, 100, 200, 300 and 500 ppm and for Brilliant Red M5B the used concentrations were 300,500 and $700 \mathrm{ppm}$. In the case of Brilliant Orange $\mathrm{H} 2 \mathrm{R}$ two experiments were carried out by varying the current strength for $500 \mathrm{ppm}$. The results are shown in the Table 1

Fig. 1. Schematic diagram of the EC cell

1. Pyrex beaker; 2. Anode; 3 . Cathode;

4. Ammeter; 5. D.C. source; 6. Variable resistance

Table 1. Comparative data for the removal of Brilliant Orange H2R and Brilliant Red M5B with time.

$[\mathrm{NaCl}]=0.01 \mathrm{M}$, Current $=0.25 \mathrm{~A}$

\begin{tabular}{|c|c|c|c|c|c|c|c|}
\hline \multirow[t]{3}{*}{ Time/min } & \multicolumn{7}{|c|}{ Percent removal } \\
\hline & \multicolumn{4}{|c|}{ Brilliant Orange H2R } & \multicolumn{3}{|c|}{ Brilliant Red M5B } \\
\hline & $\begin{array}{c}200 \mathrm{ppm} \\
(\mathrm{pH}=7.15)\end{array}$ & $\begin{array}{c}300 \mathrm{ppm} \\
(\mathrm{pH}=6.90)\end{array}$ & $\begin{array}{c}500 \mathrm{ppm} \\
(\mathrm{pH}=6.45)\end{array}$ & $\begin{array}{l}500 \mathrm{ppm}^{*} \\
(\mathrm{pH}=6.45)\end{array}$ & $\begin{array}{c}300 \mathrm{ppm} \\
(\mathrm{pH}=4.29)\end{array}$ & $\begin{array}{c}500 \mathrm{ppm} \\
(\mathrm{pH}=4.18)\end{array}$ & $\begin{array}{c}700 \mathrm{ppm} \\
(\mathrm{pH}=3.68)\end{array}$ \\
\hline 2 & 23.00 & 18.49 & 11.96 & 7.44 & 13.77 & 10.95 & 8.31 \\
\hline 5 & 92.68 & 71.92 & 14.02 & 16.53 & 34.78 & 11.94 & 13.95 \\
\hline 10 & 99.74 & 99.12 & 92.21 & 31.41 & 73.43 & 30.85 & 37.87 \\
\hline 15 & 99.88 & 99.20 & 98.36 & 57.02 & 99.80 & 64.18 & 59.80 \\
\hline 25 & & 99.93 & 98.45 & 96.03 & 99.94 & 99.90 & 99.77 \\
\hline 35 & & & 98.83 & 98.79 & & 99.96 & 99.87 \\
\hline 50 & & & 99.24 & 98.90 & & 99.97 & 99.93 \\
\hline
\end{tabular}

* Current used $=0.1 \mathrm{~A}$

(a)

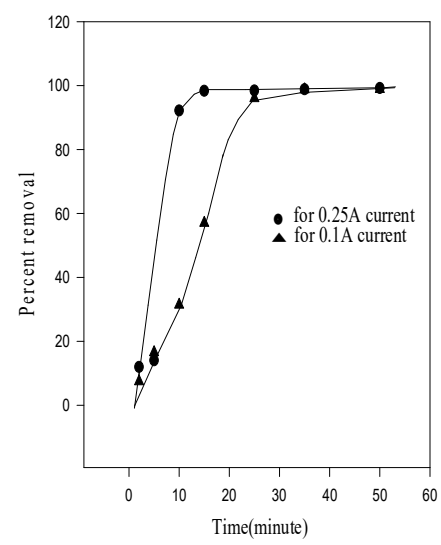

(b)

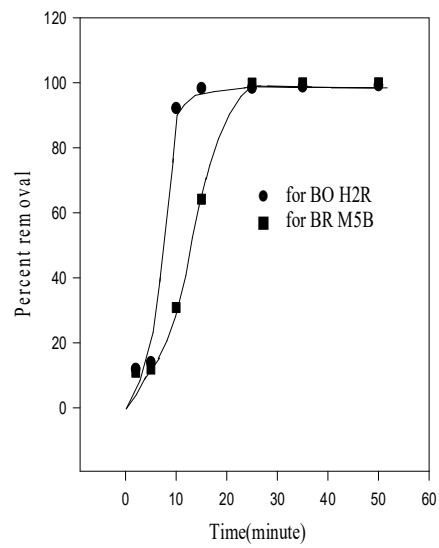

Fig. 2. Percent removal of Dye vs. time showing (a) effect of current strength for the removal of BO H2R in case of 500 ppm solution, and (b) comparison of the removal of BO H2R and BR M5B for $500 \mathrm{ppm}$ solution. 
In the present experiments when EC was carried out for 200, 300 and 500 ppm Brilliant Orange H2R (BO H2R) it was observed that $\%$ removal of dye solution was increased with time and finally almost all dye was removed [Table 1]. This is because with time the rate of oxidation of anode material increase, so enhanced amount of coagulants formed in the solution become available for coagulation with dye molecules. When the EC experiments were carried out with 10 and 20 ppm BO H2R it was seen that almost all dye was removed within 2-5 minutes. But when the concentration was increased from $100 \mathrm{ppm}$ to $200 \mathrm{ppm}$, the electrolysis period was exceeded to 10 minutes i.e. increasing the concentration of dye required increased electrolysis time for coagulation of $\mathrm{BO} \mathrm{H} 2 \mathrm{R}$. The similar results were observed for 300 and $500 \mathrm{ppm} \mathrm{BO} \mathrm{H2R.} \mathrm{The} \mathrm{EC} \mathrm{experiments} \mathrm{were}$ performed for 300, 500 and 700 ppm Brilliant Red M5B (BR M5B) keeping the EC condition unchanged and similar results were observed.

The mechanism of EC is not yet clearly understood, although it is believed that the coagulants in the present case are gelatinous suspension of $\mathrm{Fe}(\mathrm{OH})_{\mathrm{n}(\mathrm{s})}$ compound formed in-situ as a result of electrochemical process involving the 'sacrificial iron anode'. Two mechanisms have been proposed for the production of $\mathrm{Fe}(\mathrm{OH})_{\mathrm{n}}{ }^{9-11}$.

\section{Mechanism I}

Anode:

$$
\begin{aligned}
& 2 \mathrm{Fe}^{0} \rightleftharpoons 2 \mathrm{Fe}^{2+}{ }_{(\mathrm{aq})}+4 \mathrm{e}^{-} \\
& 2 \mathrm{Fe}^{2+}{ }_{(\mathrm{aq})}+5 \mathrm{H}_{2} \mathrm{O}+1 / 2 \mathrm{O}_{2(\mathrm{~g})} \\
& \rightleftharpoons 2 \mathrm{Fe}(\mathrm{OH})_{3(\mathrm{~s})}+4 \mathrm{H}^{+}{ }_{(\mathrm{aq})}
\end{aligned}
$$

Cathode: $\quad 4 \mathrm{H}^{+}{ }_{(\mathrm{aq})}+4 \mathrm{e}^{-} \rightleftharpoons 2 \mathrm{H}_{2(\mathrm{~g})}$

Overall: $\quad 2 \mathrm{Fe}^{0}+5 \mathrm{H}_{2} \mathrm{O}+1 / 2 \mathrm{O}_{2(\mathrm{~g})}$

$$
\rightleftharpoons 2 \mathrm{Fe}(\mathrm{OH})_{3(\mathrm{~s})}+2 \mathrm{H}_{2(\mathrm{~g})}
$$

Mechanism II
Anode:
$2 \mathrm{Fe}^{0} \rightleftharpoons \mathrm{Fe}^{2+}{ }_{(\mathrm{aq})}+2 \mathrm{e}^{-}$
$2 \mathrm{Fe}^{2+}{ }_{(\mathrm{aq})}+2 \mathrm{OH}_{(\mathrm{aq})}^{-} \rightleftharpoons \mathrm{Fe}(\mathrm{OH})_{2(\mathrm{~s})}$
Cathode:
$2 \mathrm{H}_{2} \mathrm{O}+2 \mathrm{e}^{-} \rightleftharpoons \mathrm{H}_{2(\mathrm{~g})}+2 \mathrm{OH}_{(\mathrm{aq})}^{-}$
Overall:$$
\mathrm{Fe}^{0}+2 \mathrm{H}_{2} \mathrm{O} \rightleftharpoons \mathrm{Fe}(\mathrm{OH})_{2(\mathrm{~s})}+\mathrm{H}_{2(\mathrm{~g})}
$$

The $\mathrm{Fe}(\mathrm{OH})_{\mathrm{n}(\mathrm{s})}$ formed in the aqueous stream can remove the pollutants from wastewater either by complexation or by electrostatic attraction, followed by coagulation ${ }^{12}$.

From the experimental results for 500 ppm BO H2R presented in Table 1, it was observed that when $0.1 \mathrm{~A}$ current was applied the removal efficiency of dye was much decreased with time interval in comparison to $0.25 \mathrm{~A}$ current [Fig. 2(a)]. The results indicate that with increasing current strength the coagulant formation rate increased and thus $\%$ removal of dye enhanced drastically. Finally from the comparative results for $\mathrm{BO} \mathrm{H} 2 \mathrm{R}$ and $\mathrm{BR}$ M5B with 500 ppm dye solution presented in Table 1 it was seen that in case of BO H2R removal efficiency was $11.96 \%$ in 2 minutes and for BR M5B it was $10.95 \%$ which is smaller in magnitude [Fig. 2(b)]. All other time intervals followed the same sequence. These results might be due to high concentration of BR M5B causing an altered range of $\mathrm{pH}$ for removal of BR M5B with coagulant ${ }^{13}$. These results showed that the removal of $\mathrm{BO} H 2 \mathrm{R}$ was much easier than that of BR M5B.

\section{Conclusion}

The treatment of reactive dyes Brilliant Orange H2R and Brilliant Red M5B by means of electrocoagulation was found to be affected by initial dye concentration and applied current strength during electrocoagulation. The results lead us to conclude that increasing the initial dye concentration require increased electrolysis time for electrocoagulation of dye and high current strength leads to an increase in percent removal of dye by electrocoagulation. Finally from the overall experimental results, taking into account the removal efficiency, electrocoagulation process can be considered as a promising process for reactive dye removal.

\section{References}

1. Copper, P., 1993. Removing colour from dyehouse waste waters, a critical review of technology available. J. Soc. Dyers Col., 109, 97-100.

2. Grau, P., 1991. Textile industry wastewaters treatment. Water Sci. Technol., 24, 97-103.

3. Hao, O.J., H. Kim and P.C. Chang, 2000. Decolorization of wastewater. Crit. Rev. Env. Sci. Tec., 30, 449-505.

4. Judkins Jr, J.F., 1984. Textile waste-water. J. Water Pollut. Control Fed., 56, 642.

5. Robinson. T., G. McMullan, R. Marchant and P. Nigam, 2001. Remediation of dyes in textile effluent: a critical review on current treatment technologies with a proposed alternative. Biores. Technol., 77, 247-255.

6. Southern, T.G., 1995. Technical solutions to the colour problem: a critical review in colour in dyehouse effluent, P. Copper (ed), Society of Dyers and Colourists: Bradford, England. p. 73-91.

7. Tunay. O., I. Kabdasli, G. Eremektar and D., Orhon, 1996. Color removal from textile wastewaters. Water Sci. Technol., 34, 9-16. 
8. Vandevivere, P. C., R. Bianchi, and W. Verstraete, 1998. Treatment and reuse of wastewater from the textile wetprocessing industry: review of emerging technologies. $J$. Chem. Technol. Biotechnol., 72, 289-302.

9. Wilcock A. E., 1992. Spectrophotometric Analysis of Electrochemically Treated, Simulated, Disperse Dyebath Effluent, Textile Chemist and Colorist, 24 (11), 29.

10. Wilcock, A. E., and S. P. Hay, 1991. Recycling of Electrochemically Treated Disperse Dye Effluent, Canadian Textile Journal, 108 (4), 37.
11. Endyuskin, P. N., S. V. Selezenkin and K. M. Dyumaev, 1983. Electrochemical purification of wastewaters from production of organic-dyes, Journal of Applied Chemistry of the Ussr, 56 (5), 1100

12. Ibanez, J. G., M. M. Singh and Z. Szafran, 1998. J. Chem. Edu., 75, 1040.

13. Pontius F. W., 1990. Water Quality and the treatment, $4^{\text {th }}$ edt., Mcgraw-Hill, New York. 
Treatment of Wastewater Containing Brilliant Orange H2R and Brilliant Red M5B by Electrocoagulation 